\title{
Groundwater
}

\section{Spatial Quantification of Groundwater Abstraction in the Irrigated Indus Basin}

by M.J.M. Cheema ${ }^{1,2}$, W.W. Immerzeel ${ }^{3,4}$, and W.G.M. Bastiaanssen ${ }^{5,6}$

\begin{abstract}
Groundwater abstraction and depletion were assessed at a $1-\mathrm{km}$ resolution in the irrigated areas of the Indus Basin using remotely sensed evapotranspiration (ET) and precipitation; a process-based hydrological model and spatial information on canal water supplies. A calibrated Soil and Water Assessment Tool (SWAT) model was used to derive total annual irrigation applied in the irrigated areas of the basin during the year 2007. The SWAT model was parameterized by station corrected precipitation data (R) from the Tropical Rainfall Monitoring Mission, land use, soil type, and outlet locations. The model was calibrated using a new approach based on spatially distributed ET fields derived from different satellite sensors. The calibration results were satisfactory and strong improvements were obtained in the Nash-Sutcliffe criterion (0.52 to 0.93$)$, bias ( $-17.3 \%$ to $-0.4 \%$ ), and the Pearson correlation coefficient (0.78 to 0.93 ). Satellite information on R and ET was then combined with model results of surface runoff, drainage, and percolation to derive groundwater abstraction and depletion at a nominal resolution of $1 \mathrm{~km}$. It was estimated that in $2007,68 \mathrm{~km}^{3}(262 \mathrm{~mm})$ of groundwater was abstracted in the Indus Basin while $31 \mathrm{~km}^{3}(121 \mathrm{~mm})$ was depleted. The mean error was $41 \mathrm{~mm} / \mathrm{year}$ and $62 \mathrm{~mm} /$ year at $50 \%$ and $70 \%$ probability of exceedance, respectively. Pakistani and Indian Punjab and Haryana were the most vulnerable areas to groundwater depletion and strong measures are required to maintain aquifer sustainability.
\end{abstract}

\section{Introduction}

Quantification of groundwater abstraction, especially in arid regions where recharge is genuinely small, is of prime importance for sustainable basin scale water

\footnotetext{
${ }^{1}$ Department of Irrigation and Drainage, University of Agriculture, Fasialabad, Pakistan.

${ }^{2}$ Corresponding author: Water Management Department, Delft University of Technology, Stevinweg 1, 2628 CN Delft, The Netherlands; 31-15-2785074; mjm.cheema@gmail.com

${ }^{3}$ Future Water, Costerweg 1G, 6702 AA Wageningen, The Netherlands.

${ }^{4}$ Department of Physical Geography, University of Utrecht, Utrecht, The Netherlands.

${ }^{5}$ Water Management Department, Delft University of Technology, Stevinweg 1, 2628 CN Delft, The Netherlands.

${ }^{6}$ eLEAF Competence Center, Generaal Foulkesweg 28, 6703 BS Wageningen, The Netherlands.

Received April 2012, accepted January 2013.

(c) 2013, National Ground Water Association.

doi: $10.1111 /$ gwat. 12027
}

resources. Long-term groundwater abstractions should not increase than the recharge but rapid population growth and increased irrigation development for food security has resulted in exhaustive groundwater abstractions in many alluvial plains (Foster and Chilton 2003; Shah et al. 2007). Siebert et al. (2010) developed a global inventory on groundwater which estimated that $43 \%$ of the total consumptive irrigation water use met through groundwater. Groundwater abstractions are temporally episodic and spatially variable and depend upon the crop irrigation needs, surface water availability, and water quality. The spatial variability in groundwater availability and water requirement by crops complicate the quantification of abstractions. The Indus Basin is a typical example showing high variability in land use, climate, canal water availability, soil types, and irrigation practices without any regulation in place to measure the groundwater abstraction.

In the Indus Basin, groundwater is utilized solely or in conjunction with surface water to augment insufficient 
and unreliable surface water supplies. Groundwater abstraction ranged between $40 \%$ and $60 \%$ of irrigation needs depending upon land uses (Scott and Shah 2004; Sarwar and Eggers 2006; Arshad et al. 2008). The continuous abstractions, in high quantities, can adversely affect the overall water balance when the average value consistently exceeds the recharge over a long period. Therefore, accurate information on spatial groundwater abstraction and depletion is immediately required to support development of management plans.

The estimation of groundwater abstraction is normally carried out using the tube well utilization factor technique or water table fluctuation method (Maupin 1999; Healy and Cook 2002; Qureshi et al. 2003). These methods become less suitable when applied at basin scale due to the poor spatial density of the point measurements.

Alternatively, data on groundwater abstraction can be derived from hydrological models. The success of these models depends primarily on availability of comprehensive input data and how well the models are calibrated (Zhang et al. 2008). Long-term time series datasets with high spatial details are difficult to obtain in spatially heterogeneous basins with a limited gauging network (Sivapalan et al. 2003). Extreme spatiotemporal variability in precipitation and evapotranspiration (ET) in combination with low density surface and groundwater point measurements makes models prone to errors, as these point measurements cannot represent the spatial variability. Measurements at few stations and their spatial extrapolation for the entire basin may yield unreliable estimates of water use. The uncertainties associated with the measured input data may also lead to biases in the model estimations (Srinivasan et al. 2010).

In this study we develop, for the first time, a detailed Soil Water Assessment Tool (SWAT) model application that encompasses the entire transboundary Indus Basin that operates at a relatively high level of spatial detail and includes all components of the hydrological cycle. The SWAT model allows comprehensive modeling of anthropogenic interventions in the hydrological cycle including irrigation, reservoirs, groundwater abstractions, and a wide variety of agricultural practices. The model was parameterized using remote sensing-derived datasets of elevation, land use and precipitation, and calibrated against remotely sensed ET at hydrological response unit (HRU) level.

This paper employs new methods to obtain groundwater information for each pixel, using satellite measurements, GIS system, and hydrological model. The main objective of the paper is to demonstrate how a smart combination of modeling and remote sensing can be used to provide more clarity on one of the largest unknowns in the hydrological cycle within the complexity of the Indus Basin. Our method identifies groundwater hotspot areas at high spatial resolution and consequently groundwater-pumping activities are no longer a hidden piece of information.

\section{Materials and Methods}

\section{Study Area}

The Indus Basin lies between latitude $24^{\circ} 38^{\prime}$ to $37^{\circ} 03^{\prime} \mathrm{N}$ and longitude $66^{\circ} 18^{\prime}$ to $82^{\circ} 28^{\prime} \mathrm{E}$ located in four countries (Figure 1). The lifeline of the Indus Basin is the Indus River that traverses China, Afghanistan, India and Pakistan, moving from upstream to the downstream end of the basin. The elevations range from 0 to $8600 \mathrm{~m}$ above mean sea level (a.m.s.l). The basin exhibits complex hydrological processes due to variability in topography, rainfall, land use, and water use. The average annual rainfall varies from less than $200 \mathrm{~mm}$ in the desert area to more than $1500 \mathrm{~mm}$ in the north and north-east of the basin. The 30-year (1961 to 1990) average reference crop evapotranspiration $\left(\mathrm{ET}_{\mathrm{o}}\right)$ varies between $650 \mathrm{~mm}$ in the northern parts and $2000 \mathrm{~mm}$ in the southern desert areas of the basin.

Water is diverted from the Indus River and its major tributaries (Jhelum, Chenab, Ravi, Beas, and Sutlej) through a network of canals to irrigate the agricultural lands. The main reason for this diversion is rainfall inadequacy to fulfill crop water requirements. However, the availability of canal water is unreliable and that has motivated farmers to augment shortages in surface water by groundwater resources (Shah et al. 2000).

Two agricultural seasons kharif (May to October) and rabi (November to April) are in practice. Wheat is the major crop grown in rabi. Rice and cotton are the major crops of kharif season.

\section{Soil and Water Assessment Tool}

The SWAT model is a process-based distributed hydrological model which provides spatial coverage of the hydrological cycle components. A comprehensive description of the model can be found in literature (Arnold et al. 1998; Srinivasan et al. 1998; Neitsch et al. 2005); however, for the convenience of our readers, the SWAT model is summarized in the following paragraphs.

SWAT provides continuous simulation of ET, percolation, return flow, storage change, surface runoff, channel routing, transmission losses, crop growth, and sediment transport (Kannan et al. 2011). SWAT was selected because it represents a simple groundwater reservoir that acts as an interface between soil moisture in the unsaturated zone, groundwater storage in the saturated zone, and surface water systems. The spatial water balance of the unsaturated zone reads as:

$$
\begin{gathered}
\Delta S_{\mathrm{us}}=\mathrm{SW}_{t}-\mathrm{SW}_{\mathrm{o}}=\sum_{i=1}^{t}\left(R_{\mathrm{SWAT}}+\mathrm{IRR}_{\mathrm{SWAT}}+C_{r}\right. \\
\left.-\mathrm{ET}_{\mathrm{SWAT}}-w_{\text {seep }}-Q_{\text {surf }}-Q_{\text {lat }}\right)
\end{gathered}
$$

where $\Delta S_{\text {us }}$ is the change in storage of the unsaturated zone $(\mathrm{mm}), \mathrm{SW}_{t}$ is the final soil water content $\left(\mathrm{mm} \mathrm{H}_{2} \mathrm{O}\right)$, $\mathrm{SW}_{\mathrm{o}}$ is the initial soil water content on day $i\left(\mathrm{~mm} \mathrm{H}_{2} \mathrm{O}\right)$, $t$ is the time (d). $\mathrm{R}_{\mathrm{SWAT}}$ is the amount of precipitation 


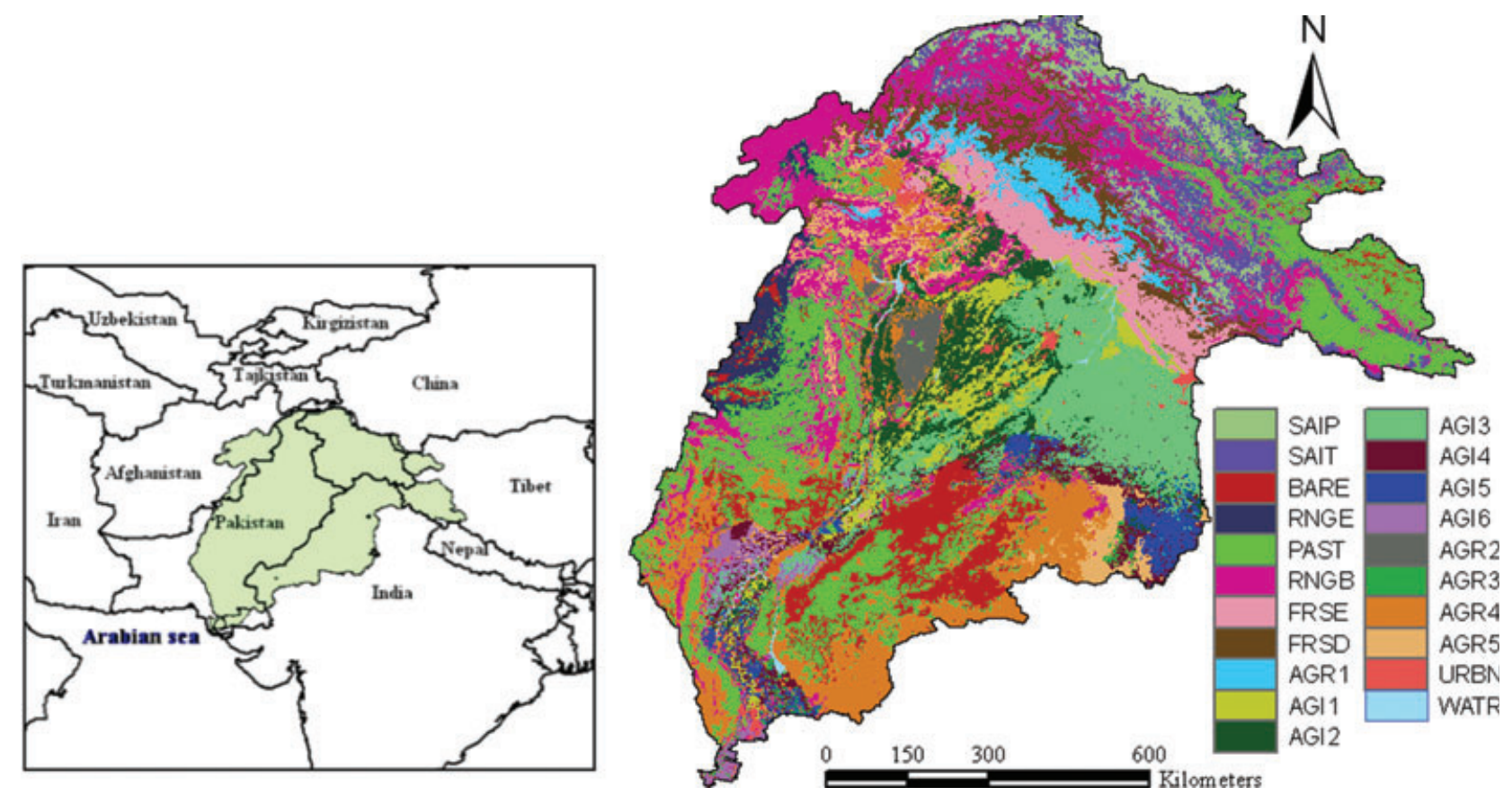

Figure 1. Location of the Indus Basin and land use scheme used in the SWAT model. The codes are explained in Table S1.

on day $i\left(\mathrm{~mm} \mathrm{H}_{2} \mathrm{O}\right), Q_{\text {surf }}$ is the amount of surface runoff on day $i\left(\mathrm{~mm} \mathrm{H}_{2} \mathrm{O}\right), \mathrm{ET}_{\text {SWAT }}$ is the amount of ET estimated by SWAT on day $i\left(\mathrm{~mm} \mathrm{H}_{2} \mathrm{O}\right), w_{\text {seep }}$ is the amount of water entering the vadose zone from the soil profile on day $i\left(\mathrm{~mm} \mathrm{H}_{2} \mathrm{O}\right)$, and $Q_{\text {lat }}$ is the amount of return flow on day $i\left(\mathrm{~mm} \mathrm{H}_{2} \mathrm{O}\right)$. IRR $\mathrm{IRWAT}_{\mathrm{SW}}$ is the amount of total irrigation applied $(\mathrm{mm})$ and $C_{r}$ is the capillary rise $(\mathrm{mm})$.

SWAT computes daily $\mathrm{ET}_{\mathrm{o}}$ and potential plant transpiration $\left(T_{\mathrm{p}}\right)$ according to meteorological input data and crop coefficients based on Penman-Monteith method (Monteith 1965). Daily crop height and leaf area index are controlling aerodynamic and canopy resistances and are used in calculating $T_{\mathrm{p}}$. Potential soil evaporation is an exponential function of $\mathrm{ET}_{\mathrm{o}}$ and the soil cover, which is reduced during periods with high plant water use. Evaporation is limited by the soil water content $(\theta)$ and is reduced exponentially when $\theta$ drops below field capacity.

The SWAT model was used to subdivide the Indus Basin into sub-basins (132 sub-basins with an average area of $8000 \mathrm{~km}^{2}$ ), which were further divided conceptually into 2459 HRUs. HRUs were based on unique and homogenous combination of land use and soil type. A total of 489 HRUs were identified as irrigated where conjunctive use was practiced. Spatially averaged data for each sub-basin on radiation, wind speed, relative humidity, air temperature, and rainfall were used to parameterize the model. Since only 1-year datasets were used, to initialize the model, especially soil moisture, a model spin-up period of 2 years was used by simulating the period January 2007 to December 2007 thrice consecutively and the calibration on ET was performed in the later year.
Data

The rainfall data in SWAT was obtained using $25-\mathrm{km}$ grids from the Tropical Rainfall Measurement Mission (TRMM) as described by Huffman et al. (2007). The products 3B42 (daily) and 3B43 (monthly) were collected for the year 2007. Daily 3B42 data were aggregated per month and a correction factor for each month was established using calibrated 3B43 monthly data (Cheema and Bastiaanssen 2012). These correction factors were used to generate corrected daily grids of rainfall ( $\mathrm{R}_{\text {TRMM }}$ ) from January 1, 2007 to December 31, 2007. The rainfall that was deposited below a threshold temperature $\left(-4{ }^{\circ} \mathrm{C}\right)$ was classified as snow.

Solar radiation was computed from the extraterrestrial radiation in association with an atmospheric transmissivity. The atmospheric transmissivity was inferred from optical depth information obtained at 1-km pixel resolution Moderate Resolution Imaging Spectro radiometer (MODIS) cloud product (MYD06_L2) downloaded from https://wist.echo.nasa.gov/ wist/api/ imswelcome/.

The spatially distributed meteorological data for maximum $\left(T_{\max }\right)$ and minimum $\left(T_{\min }\right)$ air temperature, relative humidity $(\mathrm{RH})$, and wind speed $\left(U_{2}\right)$ were prepared using meteorological distribution model (Daymet) described by Thornton et al. (1997). The meteorological station data were obtained from 65 meteorological stations under the aegis of the Pakistan Meteorological Department (PMD). Weather station data for India, China, and Afghanistan were obtained from the National Oceanic and Atmospheric Administration (NOAA) and National Climatic Data Center (NCDC). Data from 16 stations with complete datasets were available from NOAA. Thus collectively, data on air temperature, relative humidity, 
and wind speed from 81 stations were available. The gridded daily datasets were aggregated per sub-basin, which provided 132 hypothetical meteorological stations (one per sub-basin) with uniform distribution.

A detailed land use and land cover (LULC) map developed by Cheema and Bastiaanssen (2010) was used to infer information on different land uses in the Indus Basin. Twenty-seven LULC classes were classified. Those classes were clustered into 21 land use classes based on SWAT land use library. The details of seven irrigated land use classes including growing season and irrigation depths are provided in the Table S1.

The actual dates of sowing and harvesting as well as irrigation depths vary spatially and temporally. For example, wheat crop is sown between 1 and 30 November and irrigation depths may vary from 45 to $105 \mathrm{~mm}$, while number of irrigations may vary from 3 to 5 . These irrigation practices, provided by Pakistan Agricultural Research Council (PARC 1982) and Ahmad (2009), were adopted for initiation of the SWAT model.

The FAO digital soil map of the world (FAO 1995) was used to derive soil properties with the aid of pedo-transfer functions (Droogers 2006). Fortyeight different soil units were found in the basin and the alluvial plains were predominantly characterized by vertisols and the steeper slopes by fluvisols. A GTOPO30DEM was used in watershed delineation and defining streams. The surface water supplies at canal heads for various canal command areas (CCA) were obtained from Punjab Irrigation department (PID), Water and Power Development Authority (WAPDA), and Indus Water Commission (IWC), Lahore, Pakistan.

\section{ETLook}

The ETLook algorithm uses a two-layer PenmanMonteith equation (Monteith 1965) by dividing each pixel of the image into bare soil and canopy to infer evaporation $(E)$ and transpiration $(T)$, respectively (Bastiaanssen et al. 2012). The Penman-Monteith equation for $E$ and $T$ can be written as:

$$
\begin{gathered}
E=\frac{\Delta\left(R_{n, \text { soil }}-G\right)+\rho c_{p}\left(\frac{\Delta_{e}}{r_{a, \text { soil }}}\right)}{\Delta+\gamma\left(1+\frac{r_{\text {soil }}}{r_{a, \text { soil }}}\right)} \\
T=\frac{\Delta\left(R_{n, \text { canopy }}\right)+\rho c_{\mathrm{p}}\left(\frac{\Delta_{e}}{r_{a, \text { canopy }}}\right)}{\Delta+\gamma\left(1+\frac{r_{\text {canopy }}}{r_{a, \text { canopy }}}\right)}
\end{gathered}
$$

where $E$ and $T$ are in $\mathrm{W} / \mathrm{m}^{2} . G$ is soil heat flux. $\Delta$ $(\mathrm{mbar} / \mathrm{K})$ is the slope of the saturation vapor pressure curve which is a function of air temperature $\left(T_{\text {air }},{ }^{\circ} \mathrm{C}\right)$ and saturation vapor pressure $\left(e_{\mathrm{s}}\right.$, mbar); $\Delta_{e}$ (mbar) is vapor pressure deficit, which is the difference between the saturation vapor content and the actual vapor content; $\rho\left(\mathrm{kg} / \mathrm{m}^{3}\right)$ is the air density and $\mathrm{c}_{\mathrm{p}}$ is specific heat of dry air $=1004 \mathrm{~J} / \mathrm{kg} / \mathrm{K} ; \gamma(\mathrm{mbar} / \mathrm{K})$ is the psychometric constant; $R_{n \text {,soil }}$ and $R_{n \text {,canopy }}$ are the net radiations at soil and canopy, respectively; $r_{\text {soil }}$ and $r_{\text {canopy }}$ are resistances of soil and canopy, while $r_{a \text {,soil }}$ and $r_{a \text {,canopy }}$ are aerodynamic resistances for soil and canopy. All resistances are in s/m. Total ET is the sum of $T$ and $E$ and the units can be converted to $\mathrm{mm} / \mathrm{d}$. In this study, the $E T$ data is available with an eight day interval for the period of one calendar year from January 1 to December 31, 2007.

\section{Model Calibration Procedure}

The calibration of the SWAT model was performed by comparing SWAT modeled ET (ET SWAT $_{\text {}}$ ) with ET estimated by ETLook at 1-km pixel (ET ETLook ) for all HRUs. In complex distributed hydrological model having numerous parameters with a high spatial and temporal heterogeneity, using conventional stream flow calibration with limited number of discharge stations may lead to the equifinality problems, for example, there are more than one parameter combination leading to similar results (Beven and Freer 2001; Beven 2006). Moreover, calibration becomes ineffective in basins, such as the Indus, where stream flow is under human control (Immerzeel and Droogers 2008).

A stepwise heuristic iterative approach was therefore adopted to perform calibration by adjusting the key soil and groundwater parameters. A number of important model parameters, which have a large influence on ET, were used in the model calibration. The sensitive parameters that control $E$ and $T$ fluxes were identified from the previous literature (Immerzeel and Droogers 2008; Immerzeel et al. 2008; Githui et al. 2012; Kannan et al. $2011)$. The soil water holding capacity $(\Phi)$, capillary rise $\left(C_{r}\right)$, depth of the evaporation front $(\Psi)$, and the relative water uptake by plant roots as a function of soil moisture $\left(w_{\text {up }, z}\right)$ were calibrated. Their allowable ranges were bound to 0.06 to $0.60 \mathrm{~mm} / \mathrm{mm}$ for $\Phi, 0.02$ to 0.9 for $C_{r}$, 0.01 to 1.0 for $\Psi$ and 0.01 to 1.0 for $w_{\text {up }, z}$ (Neitsch et al. 2005; Immerzeel and Droogers 2008; Immerzeel et al. 2008). $\Phi, \Psi, C_{r}$ and $w_{\text {up }, z}$ coefficients were optimized for each HRU. Most parameters were optimized per HRU of each land use class to capture the spatial heterogeneity because land use information is available at relatively detailed level compared with the soil type information. Default values of these parameters were adopted for the base run and implemented adjustments were constrained by the ranges of parameters suggested by Neitsch et al. (2005).

Three common statistical indicators, as described by Hoffmann et al. (2004), were used to quantify the achieved level of calibration and to evaluate the SWAT model's overall performance. The Nash-Sutcliffe model efficiency (NSE) (Nash and Sutcliffe 1970), Pearson's correlation coefficient ( $r$ ), and percent bias (Pbias) between modeled and estimated ET were determined, which are given as:

$$
\mathrm{NSE}=1-\frac{\sum_{i=1}^{n}\left(e_{i}-m_{i}\right)^{2}}{\sum_{i=1}^{n}\left(e_{i}-\bar{e}_{i}\right)^{2}}
$$




$$
\begin{gathered}
r=\frac{\sum_{i=1}^{n}\left(e_{i}-\bar{e}\right)\left(m_{i}-\bar{m}\right)}{\sqrt{\sum_{i=1}^{n}\left(e_{i}-\bar{e}\right)^{2} \sum_{i=1}^{n}\left(m_{i}-\bar{m}\right)^{2}}} \\
P \text { bias }=\left(\frac{\sum_{i=1}^{n}\left(m_{i}-e_{i}\right)}{\sum_{i=1}^{n} e_{i}}\right) \times 100
\end{gathered}
$$

where $e$ represents the ET estimated by ETLook $\left(\mathrm{ET}_{\mathrm{ETLook}}\right)$ and $m$ represents the modeled (ET $\left.\mathrm{ET}_{\mathrm{SWAT}}\right) \mathrm{ET} . \bar{e}$ is the mean of $\mathrm{ET}_{\mathrm{ETLook}}$ and $n$ is the total number of observations. NSE ranges between $-\infty$ and 1 , with NSE $=1$ being the optimal value. Pearson's $r$ ranges between -1 and +1 , with $r=1$ being optimal value. The Pbias reveals to which degree the modeled value is smaller or larger than the estimated values given in percentage and close to zero is preferred.

\section{Pixel-Based Groundwater Abstraction Data}

The pixel information on ET $_{\text {ETLook }}$ and rainfall $\left(\mathrm{R}_{\text {TRMM }}\right)$ from TRMM is valuable additional spatial information. This information can be used to infer total irrigation water supply at the farm gate for each pixel (IRR $R_{R S}$ ), when being integrated with HRU fluxes obtained from SWAT calculations of Equation 1. Assuming that capillary rise and storage changes to be part of applied water, the analytical expression becomes:

$$
\begin{aligned}
\mathrm{IRR}_{\mathrm{RS}} & =\Delta S_{\mathrm{us}}+\mathrm{ET}_{\mathrm{ETLook}}+Q_{\text {surf }}+Q_{\text {lat }} \\
& +Q_{\text {perc }}-R_{\mathrm{TRMM}}
\end{aligned}
$$

Irrigation water, diverted to main canals irrigating a specific CCA, was aggregated to monthly and annual irrigation volumes. The resulting vector maps of canal water supplies for each CCA were prepared. The supplies were then converted into depths by dividing over the area of each CCA. The result was a canal irrigation vector map $\left(I_{R R_{c w}}\right)$. The overlay helped to partition total irrigation water supply (IRR $\left.R_{R S}\right)$ into canal irrigation $\left(\mathrm{IRR}_{\mathrm{cw}}\right)$ and gross groundwater abstraction from shallow aquifer $\left(\mathrm{IRR}_{\mathrm{gw}}\right)$ :

$$
\mathrm{IRR}_{\mathrm{gw}}=\mathrm{IRR} \mathrm{RS}_{\mathrm{RS}}-\mathrm{IRR}_{\mathrm{cw}} .
$$

The annual depths of canal water varied from 200 to $1700 \mathrm{~mm}$ per diversion. Conveyance efficiency of $70 \%$ was considered for canals in Pakistani part of the Indus Basin (Habib 2004; Arshad et al. 2005; Kreutzmann 2011) and $80 \%$ for canals in Indian part of the Indus Basin (Bastiaanssen et al. 1999; Kroes et al. 2003; Jeevandas et al. 2008).
The net groundwater depletion $\left(\mathrm{DEP}_{\mathrm{gw}}\right.$ : amount of water leaving the shallow aquifer) was estimated for the irrigated areas using information of canal water losses $\left(\mathrm{LOSS}_{\mathrm{cw}}\right)$ as:

$$
\mathrm{DEP}_{\mathrm{gw}}=\mathrm{IRR}_{\mathrm{gw}}+Q_{\mathrm{gw}}-Q_{\mathrm{perc}}-\mathrm{LOSS}_{\mathrm{cw}} .
$$

Note that the capillary rise is considered as a component of the irrigation water supply.

\section{Results and Discussion}

\section{Model Calibration}

The model performance was evaluated using three statistical indicators namely NSE, Pearson's $r$, and Pbias. The performance was assessed at sub-basin and HRU levels. At sub-basin level, NSE of the calibrated model was 0.93 , while under un-calibrated conditions the NSE was 0.52. Improvement in Pearson's $r$ was observed from 0.78 to 0.97 , suggesting a strongly improved correlation between $\mathrm{ET}_{\mathrm{SWAT}}$ and $\mathrm{ET}_{\mathrm{ETLook}}$ when model parameters were adjusted according to the existing ET layers from the energy balance. The Pbias resulted in $-0.4 \%$, which was very low as compared to $-17.3 \%$ (base run) indicating no systematic under or over prediction of ET was observed at sub-basin level. Figure 2 shows the correspondence between the modeled and ETLook estimated ET at subbasin scale.

Figure 3 shows the results for 489 HRUs that contain irrigated land only. The NSE, Pbias, and Pearson's $r$ were $0.93,-2.3$, and 0.97 . This level of agreement shows that SWAT can produce ET values from the soil water balance that is very similar to the ET of irrigated crops as interpreted from satellite images. The spatial pattern of ET modeled by SWAT was in good agreement with $\mathrm{ET}_{\mathrm{ETLook}}$. However, some local differences were observed and the reason is that $\mathrm{ET}_{\mathrm{SWAT}}$ results showed larger differences within land use variation.

Figure 4 provides more insight into the temporal ET patterns. The ET showed good agreement between the monthly $\mathrm{ET}_{\mathrm{SWAT}}$ and $\mathrm{ET}_{\mathrm{ETLook}}$ with a correlation coefficient $\left(R^{2}\right)$ of 0.87 . November and December showed low ET rate due to lower solar altitudes and low ambient temperature. The warm atmosphere and large rainfall amounts due to monsoon system were the reasons of peak ET rates during July. The strong reduction in ET during the month of May - when land was being prepared for the summer crop-was picked up well by SWAT.

It is notable that in the months of September to November, $\mathrm{ET}_{\mathrm{ETLook}}$ was higher than the modeled values while the reverse was observed for the months of June and July. One of the main reasons is that most of the fields became fallow due to the harvest of kharif crops. Normally harvesting starts at different dates at different locations depending upon the crop maturity. However, in SWAT parameterization each land use was assigned with a single date of harvesting. The moisture retained especially in paddy fields, contributed to evaporation thus 


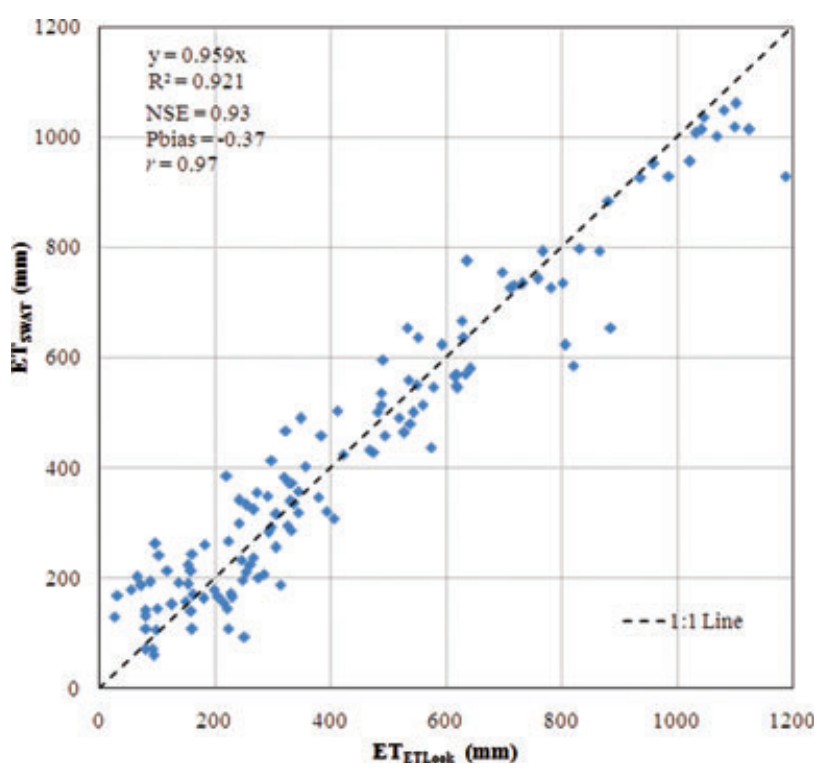

Figure 2. Comparison between modeled (ET $\left.\mathbf{S W A T}_{\mathrm{S}}\right)$ and estimated $\left(\mathbf{E T}_{\text {ETLook }}\right)$ evapotranspiration for 132 sub-basins in the Indus Basin.

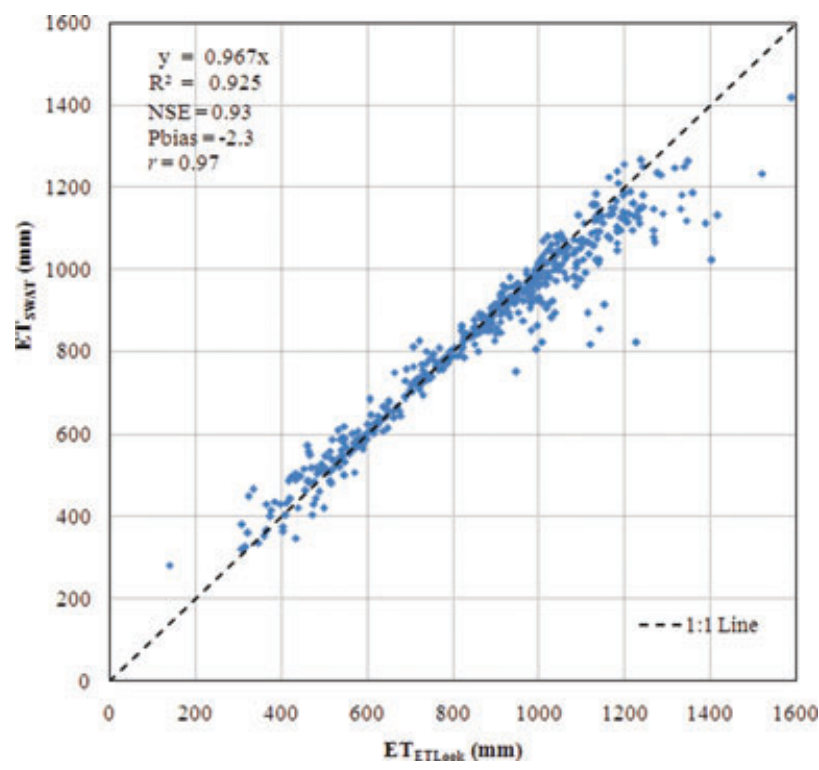

Figure 3. Comparison between modeled (ET $\mathbf{S W A T}_{\mathrm{SW}}$ ) and

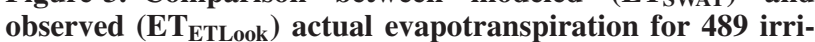
gated HRUs.

causing higher $\mathrm{ET}_{\mathrm{ETLook}}$ than the $\mathrm{ET}_{\mathrm{SWAT}}$. During the month of August, $\mathrm{ET}_{\text {ETLook }}$ was higher than ET $\mathrm{ET}_{\mathrm{SWA}}$ because water was stagnated in the paddy fields causing higher ET values. In contrary, during the months of June and July, ET SWAT $_{\text {showed higher values. These } 2 \text { months }}$ correspond to the monsoon months with higher rainfall and considerable irrigation was supplied to the crops especially to rice and cotton. It suggests that $\mathrm{ET}_{\mathrm{SWAT}}$ overestimates ET during these months.

Moreover, during model simulations, the specified irrigation dates for a particular crop were the same for the HRUs representing that crop. It was assumed that

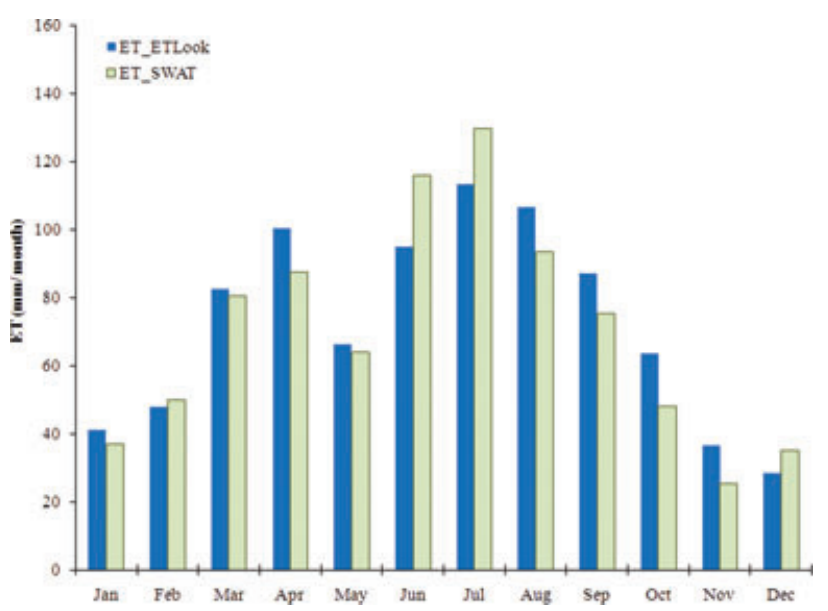

Figure 4. Comparison of monthly ET ETLook $_{\text {against }}$ ET $_{\text {SWAT }}$ for all 489 irrigated HRU's during 2007.

the total area under that particular crop was irrigated on the specified date and specified depths. In reality, the irrigation of a particular crop was completed over a period of time depending on the farmer's rotation for canal supplies. Another source of temporal discrepancy could be that during the simulation periods canal water supply to a certain CCA was taken as constant for the entire command area. In reality it varied based on the distance from the canal head. All these factors can be the cause of deviations.

Overall it can be concluded that the calibration on actual ET is highly satisfactory given the high correlation, NSE, and low biases. The Indus SWAT model was calibrated at the highest possible spatial detail (HRU level) and the temporal ET patterns were also simulated with reasonable accuracy. The adopted calibration strategy is effective and outperforms earlier work in this field (e.g., Immerzeel and Droogers 2008).

\section{Spatial Patterns of Water Supply and Consumption}

The spatial distribution of total irrigation estimated by applying pixel information ( $\left(\mathrm{IRR}_{\mathrm{RS}}\right)$, canal water supplied at farm gate $\left(\operatorname{IRR}_{\mathrm{cw}}\right)$, and percolation to aquifer $\left(Q_{\text {perc }}\right)$ are provided in Figure S1a to S1c, Supporting Information. Gross irrigation from groundwater $\left(\mathrm{IRR}_{\mathrm{gw}}\right)$ and related groundwater depletion $\left(\mathrm{DEP}_{\mathrm{gw}}\right)$ are presented in Figure 5a and $5 \mathrm{~b}$. The total canal water available at the farm gate for each canal command was estimated at $113 \mathrm{~km}^{3}$ (or $434 \mathrm{~mm}$ ) (Figure S1a). This amount was computed from the reservoir releases and reported conveyance losses. Canal water available at farm gates varied from 200 to $900 \mathrm{~mm} /$ year. This spatial variability in canal supplies was due to the nonperennial system and variability in water released from the reservoirs.

The total irrigation estimated by pixel information (IRR RS) using Equation 7 was $181 \mathrm{~km}^{3}(696 \mathrm{~mm})$. Total applied water varied between 200 to $1400 \mathrm{~mm} /$ year in the irrigated areas across the basin (Figure S1b). Higher rates of $I_{R R}$ were found in lower Indus (irrigated areas of Sindh province). IRR $_{R S}$ was also higher in Punjab 
province of Pakistan and India and Haryana. The reason of higher irrigation was large-scale cultivation of high water consumptive crops like rice, sugarcane, cotton, and so on.

Aquifer recharge $\left(Q_{\text {perc }}\right)$ ranged between 10 and $600 \mathrm{~mm}$ during the year as depicted in Figure S1c. A percolation of $71 \mathrm{~mm}$ from irrigated fields (especially in irrigated rice - wheat land use) and high rainfall during monsoon were the possible sources of this recharge. The losses from canals $\left(\mathrm{LOSS}_{\mathrm{cw}}=144 \mathrm{~mm}\right.$ ) also contributed to the aquifer.

The canal water supplies were not sufficient to meet the crop water requirements. The deficit was met through groundwater irrigation and Figure 5a shows gross groundwater abstraction $\left(\mathrm{IRR}_{\mathrm{gw}}\right)$ for each pixel estimated using Equation 8. On annual basis, an amount of 300 to $900 \mathrm{~mm}$ was abstracted from the aquifer to irrigate crops. The highest $\mathrm{IRR}_{\mathrm{gw}}$ was observed in middle and northeastern parts of the basin. These areas contain relatively good quality groundwater resources (Arshad et al. 2007) and are located in the Punjab province of Pakistan and the Indian states of Punjab and Haryana.

The largest groundwater abstraction in Pakistan occurred in the province of Punjab. The possible reason of high groundwater abstraction was the irrigation to paddy fields where canal water was not suffice. Conjunctive use of groundwater with surface water was a normal practice in those areas. In Sindh Province, groundwater abstraction was fragmented due to poor quality of groundwater.

(a)

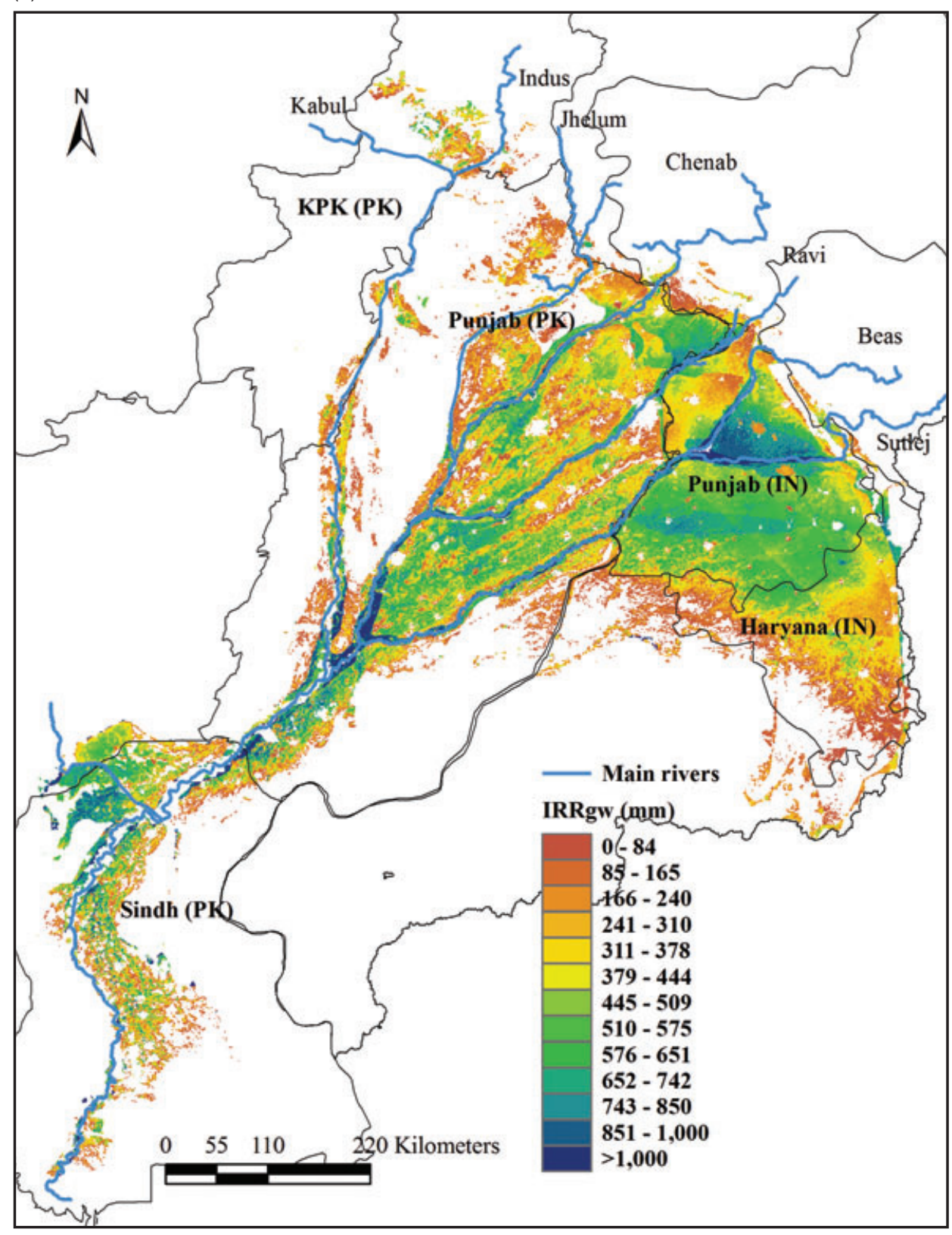

Figure 5. (a) Spatial map of gross groundwater abstraction in the irrigated Indus Basin. (b) Spatial map of net groundwater depletion in the irrigated Indus Basin. 


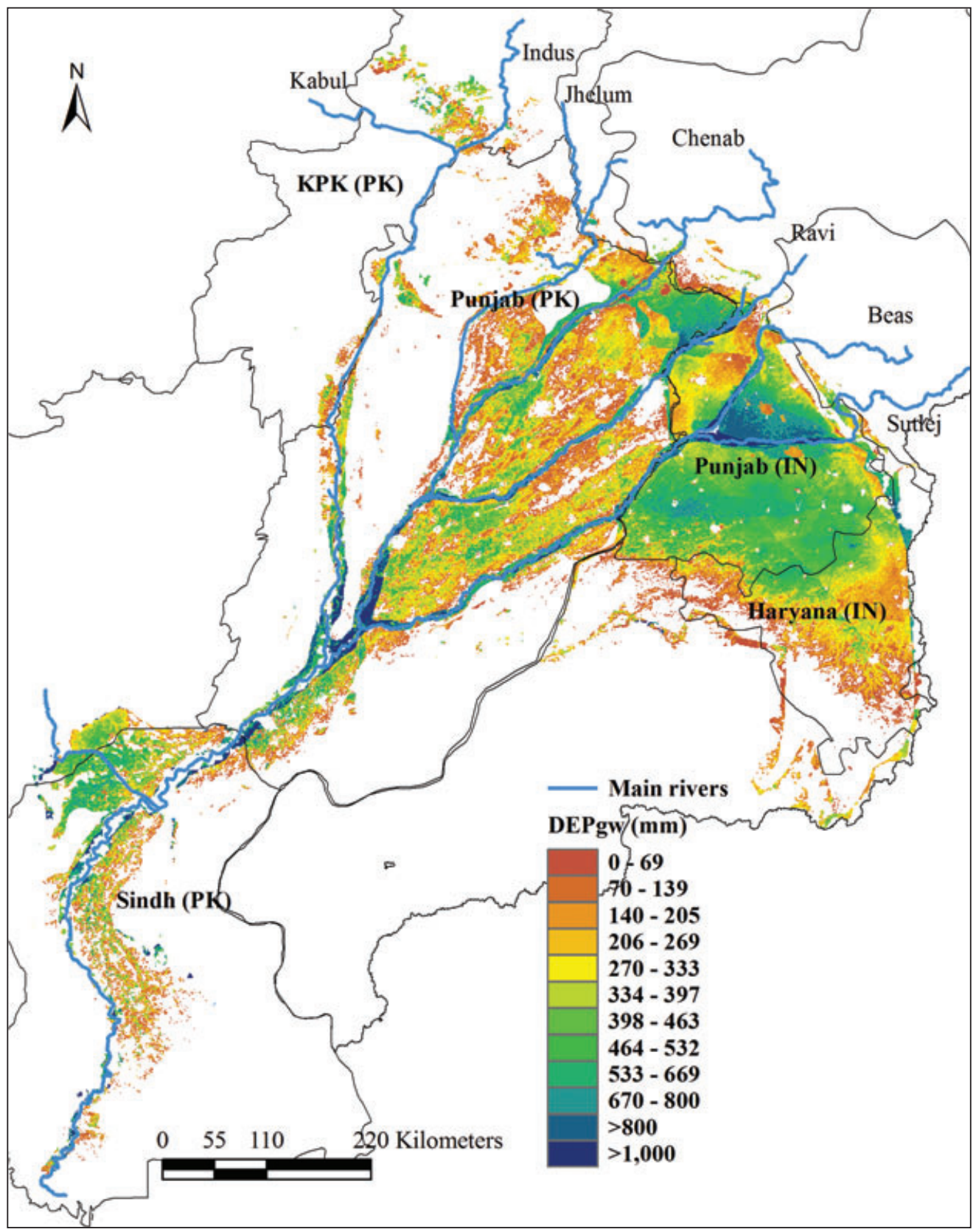

Figure 5. Continued.

However, groundwater recharge by percolation from fields and canals resulted in conjunctive use of groundwater and surface water in the northern Sindh Province (Siebert et al. 2010).

Indian states of Punjab and Haryana were also vulnerable to extensive groundwater pumping. The value ranged between 400 and $900 \mathrm{~mm}$. Irrigated rice, wheat rotation was the dominant land use that required extensive irrigation to meet crop water demand. The surface water supplies were not sufficient to meet the need therefore the deficit was met through groundwater. Large number of small capacity tubewells was installed to pump groundwater. According to Shankar et al. (2011), tubewell density in the Punjab and Haryana states was 27 and 14.1 tubewells $/ \mathrm{km}^{2}$ in 2001 and the number is increasing. The flow rates may vary from 5 to $15 \mathrm{l} / \mathrm{s}$.

The total irrigation supplies in the irrigated areas of the Indus Basin were estimated at $181 \mathrm{~km}^{3}$, an amount of $68 \mathrm{~km}^{3}$ originated from groundwater, while the surface water contribution was $113 \mathrm{~km}^{3}$. This diagnosis suggests that groundwater supplies $68 / 181$ or $38 \%$ of the total water applied at the farm gate. The results are in agreement with the $40 \%$ to $50 \%$ groundwater contribution reported by Sarwar and Eggers (2006).

The gross groundwater abstraction can be explored further to quantify the aquifer depletion (Figure $5 \mathrm{~b}$ ). The total depletion of $31 \mathrm{~km}^{3}$ (121 mm/year) in the aquifer was computed from $\operatorname{IRR}_{\mathrm{gw}}$ and the return flow $Q_{\mathrm{gw}}$. The 
Table 1

Water Balance Components for the Irrigated Areas in the Indus Basin for the Year 2007

\begin{tabular}{|c|c|c|c|c|c|c|c|c|c|c|}
\hline & $\begin{array}{c}E T_{\text {ETLook }} \\
(\mathbf{m m}) \\
\left(\mathrm{km}^{3}\right)\end{array}$ & $\begin{array}{c}\boldsymbol{R}_{\text {TRMM }} \\
(\mathbf{m m}) \\
\left(\mathrm{km}^{3}\right)\end{array}$ & $\begin{array}{l}Q_{\text {surf }} \\
(\mathbf{m m}) \\
\left(\mathbf{k m}^{3}\right)\end{array}$ & $\begin{array}{l}Q_{\text {perc }} \\
(\mathbf{m m}) \\
\left(\mathbf{k m}^{3}\right)\end{array}$ & $\begin{array}{c}\text { IRR }_{\mathbf{R S}} \\
\left(\mathrm{mm}^{\mathbf{3}}\right) \\
\left(\mathrm{km}^{3}\right)\end{array}$ & $\begin{array}{c}\mathbf{I R R}_{\mathrm{cw}} \\
(\mathbf{m m}) \\
\left(\mathbf{k m}^{\mathbf{3}}\right)\end{array}$ & $\begin{array}{c}\mathrm{IRR}_{\mathbf{g w}} \\
(\mathbf{m m}) \\
\left(\mathbf{k m}^{3}\right)\end{array}$ & $\begin{array}{c}\mathbf{L O S S}_{\mathbf{c w}} \\
(\mathbf{m m}) \\
\left(\mathbf{k m}^{3}\right)\end{array}$ & $\begin{array}{c}Q_{\mathrm{gw}} \\
(\mathbf{m m}) \\
\left(\mathbf{k m}^{3}\right)\end{array}$ & $\begin{array}{c}\mathrm{DEP}_{\mathbf{g w}} \\
(\mathbf{m m}) \\
\left(\mathbf{k m}^{3}\right)\end{array}$ \\
\hline Indus Basin & $\begin{array}{l}974 \\
(254)\end{array}$ & $\begin{array}{l}451 \\
(117)\end{array}$ & $\begin{array}{l}97 \\
(25)\end{array}$ & $\begin{array}{l}75 \\
(19)\end{array}$ & $\begin{array}{l}696 \\
(181)\end{array}$ & $\begin{array}{l}434 \\
(113)\end{array}$ & $\begin{array}{r}262 \\
(68)\end{array}$ & $\begin{array}{l}144 \\
(38)\end{array}$ & $\begin{array}{l}79 \\
(20)\end{array}$ & $\begin{array}{l}121 \\
(31)\end{array}$ \\
\hline
\end{tabular}

Table 2

Annual Water Balance Components and Computed Gross Groundwater Abstraction at Seven Selected Locations

\begin{tabular}{|c|c|c|c|c|c|c|c|c|c|c|c|}
\hline \multirow[b]{2}{*}{ Pixel Location } & \multirow{2}{*}{$\begin{array}{l}\text { Land } \\
\text { Use }\end{array}$} & \multirow{2}{*}{$\begin{array}{l}\text { ET }_{\text {ETLook }} \\
\quad(\mathbf{m m})\end{array}$} & \multirow{2}{*}{$\begin{array}{c}\mathbf{R}_{\text {TRMM }} \\
(\mathbf{m m})\end{array}$} & \multirow{2}{*}{$\begin{array}{r}Q_{\text {surf }} \\
(\mathrm{mm})\end{array}$} & \multirow{2}{*}{$\begin{array}{l}Q_{\text {perc }} \\
(\mathbf{m m})\end{array}$} & \multirow{2}{*}{$\underset{(\mathbf{m m})}{Q_{\text {lat }}}$} & \multirow{2}{*}{$\begin{array}{c}\mathbf{I R R}_{\mathrm{cw}} \\
(\mathbf{m m})\end{array}$} & \multirow{2}{*}{$\begin{array}{c}\mathbf{I R R}_{\mathrm{gw}} \\
(\mathbf{m m})\end{array}$} & \multicolumn{3}{|c|}{$\begin{array}{l}\text { AD of IRR } \mathbf{g w}_{\mathrm{gw}} \\
(\mathrm{mm}) \text { at } \mathbf{E P}\end{array}$} \\
\hline & & & & & & & & & $100 \%$ & $70 \%$ & $50 \%$ \\
\hline $\begin{array}{l}32^{\circ} 25^{\prime} 48.12^{\prime \prime} \mathrm{N} \\
73^{\circ} 24^{\prime} 39.23^{\prime \prime} \mathrm{E}\end{array}$ & AGI1 & 1311 & 767 & 131 & 70 & 0 & 722 & 23 & 213 & 84 & 54 \\
\hline $\begin{array}{l}31^{\circ} 17^{\prime} 34.54^{\prime \prime} \mathrm{N} \\
73^{\circ} 04^{\prime} 37.52^{\prime \prime} \mathrm{E}\end{array}$ & AGI2 & 1174 & 409 & 50 & 48 & 0 & 365 & 498 & 122 & 47 & 30 \\
\hline $\begin{array}{l}31^{\circ} 07^{\prime} 05.83^{\prime \prime} \mathrm{N} \\
75^{\circ} 42^{\prime} 18.35^{\prime \prime} \mathrm{E}\end{array}$ & AGI3 & 1202 & 580 & 237 & 169 & 0 & 230 & 798 & 142 & 51 & 33 \\
\hline $\begin{array}{l}30^{\circ} 08^{\prime} 49.02^{\prime \prime} \mathrm{N} \\
75^{\circ} 28^{\prime} 58.89^{\prime \prime} \mathrm{E}\end{array}$ & AGI3 & 1265 & 429 & 59 & 53 & 3 & 359 & 592 & 124 & 50 & 33 \\
\hline $\begin{array}{l}32^{\circ} 06^{\prime} 42.44^{\prime \prime} \mathrm{N} \\
73^{\circ} 49^{\prime} 32.15^{\prime \prime} \mathrm{E}\end{array}$ & AGI3 & 1098 & 579 & 163 & 105 & 0 & 348 & 439 & 148 & 52 & 35 \\
\hline $\begin{array}{l}28^{\circ} 07^{\prime} 17.29^{\prime \prime} \mathrm{N} \\
67^{\circ} 59^{\prime} 16.69^{\prime \prime} \mathrm{E}\end{array}$ & AGI6 & 1316 & 148 & 24 & 37 & 0 & 534 & 695 & 131 & 62 & 42 \\
\hline $\begin{array}{l}28^{\circ} 27^{\prime} 13.85^{\prime \prime} \mathrm{N} \\
68^{\circ} 28^{\prime} 35.80^{\prime \prime} \mathrm{E}\end{array}$ & AGI6 & 1361 & 183 & 16 & 23 & 0 & 800 & 417 & 175 & 86 & 60 \\
\hline Average & & 1246 & 442 & 97 & 72 & 0.4 & 480 & 494 & 151 & 62 & 41 \\
\hline
\end{tabular}

return flow, for example, base flow from the groundwater to the surface water system, of non-consumed water that was fed back into the river network $\left(20 \mathrm{~km}^{3} /\right.$ year $)$ was included in the analysis. The net groundwater abstracted (gross abstraction $68 \mathrm{~km}^{3} /$ year minus recharge from leaking fields and canals $57 \mathrm{~km}^{3} /$ year) became $11 \mathrm{~km}^{3}$ or $42 \mathrm{~mm} /$ year. The details of water balance components are given in Table 1.The largest net groundwater depletion $\left(\mathrm{DEP}_{\mathrm{gw}}\right)$ occurred in Punjab Province of India (200 to $800 \mathrm{~mm} /$ year). Jeevandas et al. (2008) estimated a net deficit of $260 \mathrm{~mm}$ between crop consumptive use and surface supplies in Punjab Province of India. The Haryana state of India was also vulnerable to serious groundwater depletion developments (400 to $600 \mathrm{~mm} /$ year). A recent assessment of groundwater abstractions by NASA showed that the three states of India (i.e., Punjab, Haryana, and Rajasthan) lost about $109 \mathrm{~km}^{3}$ of water during 2002 to 2008 leading to decline in water table of $330 \mathrm{~mm} / \mathrm{year}$ (Rodell et al. 2009).The groundwater overdraft at this alarming rate could potentially change the transboundary groundwater flow between India and Pakistan as also documented in IUCN (2010).

\section{Accuracy Assessment}

The usability of the $\mathrm{IRR}_{\mathrm{gw}}$ information for carrying out water management plans depends on the accuracy of the estimates. The influence of uncertainty in ET, rainfall, SWAT outputs, and canal supplies on $\mathrm{IRR}_{\mathrm{gw}}$ computations based on Equations 7 and 8 were tested. Seven pixels representing "irrigated cotton, wheat rotation/sugarcane," "irrigated cotton, wheat rotation/orchards," "irrigated rice, wheat rotation," and "irrigated rice, fodder rotation" were randomly selected. The locations of these land uses are provided in the Table 2. Bastiaanssen et al. (2012) estimated $\pm 4 \%$ uncertainty in ET $_{\text {ETLook }}$ estimates while $\mathrm{R}_{\text {TRMM }}$ have deviation of $\pm 6 \%$ at annual scale (Cheema and Bastiaanssen 2012). The errors in $I_{R R}$ were taken as $\pm 15 \%$ (Habib 2004; Ahmad et al. 2005). The error in SWAT model output parameters (e.g., $Q_{\text {surf }}, Q_{\text {perc }}, Q_{\text {lat }}$ ) are taken as $\pm 15 \%$ (Harmel et al. 2006). 
One thousand pairs of data series were randomly generated to estimate $\mathrm{IRR}_{\mathrm{gw}}$ using the uncertainty range of $\pm 4, \pm 6, \pm 15$, and $\pm 15 \%$ for $E_{\text {ETLook }}, R_{T R M M}, I R R_{c w}$, and SWAT model outputs, respectively. For all seven locations the absolute deviation was plotted against its probability of occurrence (not shown here). The maximum absolute error (100\% probability), ranged between 122 and $213 \mathrm{~mm}$ with an average of $151 \mathrm{~mm}$ (Table 2). There was $70 \%$ probability that the absolute error in $\mathrm{IRR}_{\mathrm{gw}}$ remained within $62 \mathrm{~mm} /$ year. The mean error at $50 \%$ probability of exceedance was $41 \mathrm{~mm} /$ year. In the areas with high groundwater abstraction rate $(>400 \mathrm{~mm} / \mathrm{year})$, this error can be considered within acceptable range (Ahmad et al. 2005).

\section{Conclusions}

Irrigation is the largest consumer of water in the Indus Basin that is using both surface $\left(113 \mathrm{~km}^{3}\right.$ or $\left.434 \mathrm{~mm}\right)$ and groundwater $\left(68 \mathrm{~km}^{3}\right.$ or $\left.262 \mathrm{~mm}\right)$ to meet the crop water requirements. Uncontrolled groundwater abstraction, consistently exceeding recharge, is threatening the groundwater reserves in the basin but difficult to estimate. By using remote sensing information in combination with GIS data on canal flows and SWAT model outputs, a spatial estimate of the groundwater abstractions and depletions over the entire irrigated area of the Indus Basin was obtained at a resolution of $1 \mathrm{~km}$.

The parameterization and calibration of SWAT model was based on satellite data on land use, rainfall and topography (parameterization), and actual ET (for calibration). The calibration results were satisfactory and strong improvements were obtained in the Nash-Sutcliffe criterion $(0.52$ to 0.93$)$, bias $(-17.3 \%$ to $-0.4 \%)$, and the Pearson correlation coefficient $(0.78$ to 0.93$)$. The groundwater abstraction and depletion estimates thus obtained suggested that total $68 \mathrm{~km}^{3}$ (262 mm) of groundwater was abstracted in the Indus Basin while $31 \mathrm{~km}^{3}(121 \mathrm{~mm})$ was depleted during the year 2007. The mean error was $41 \mathrm{~mm} /$ year and $62 \mathrm{~mm} /$ year at $50 \%$ and $70 \%$ probability of exceedance, respectively. The spatial maps of groundwater abstraction and depletion identify the hot spots that need special attention of water management experts. Pakistani and Indian Punjab and Haryana were the most vulnerable areas to groundwater depletion and strong measures are required to maintain aquifer sustainability.

The only solution to safeguard access to water for food and environment is to reduce groundwater abstractions. Net depletion should be virtually neutral averaged over longer time period. This can be achieved by negotiating groundwater abstractions using the maps provided in Figure 5a and 5b. Monitoring of groundwater abstraction can be implemented using the same methodology and procedures as outlined in this paper. The technological procedures are outlined and validated. Recharge by constructing wells or delay action dams should be facilitated. The role of trans-boundary aquifers should be given equal importance as the attention that goes to surface water exchanges between administrative boundaries.
The analysis is based only on one year and needs more years to consider. There is also a potential problem of limited validation as no information on spatial groundwater abstraction is available. The use of single conveyance efficiency is cautious. Conveyance efficiency based on per unit length of the canal should be tested in the future studies.

\section{Acknowledgment}

The authors are thankful to the Higher Education Commission (HEC) of Pakistan for providing funds to carry out this research. Thanks also goes to the PID, WAPDA and IWC, in Pakistan, for providing required data. Dr. Peter Droogers, of Future Water, kindly provided the soil physical properties required to delineate basin's soils. The authors are also thankful to three anonymous reviewers for their valuable suggestions to improve the manuscript.

\section{Supporting Information}

Additional Supporting Information may be found in the online version of this article:

Table S1. Land use and land cover classes in the Indus Basin. The cropping period and number of irrigation with depths are also provided for irrigated land use classes.

Figure S1. (a) Spatial map of Canal water supplies. (b) Spatial map of irrigation estimated using remote sensing products. (c) Spatial map of percolation.

\section{References}

Ahmad, S. 2009. Water availability in Pakistan. Paper presented at National Seminar on Water Conservation, Present Situation and Future Strategy, Project Management \& Policy Implementation Unit (PMPIU) of the Ministry of Water \& Power, Islamabad, Pakistan.

Ahmad, M.D., W. Bastiaanssen, and R. Feddes. 2005. A new technique to estimate net groundwater use across large irrigated areas by combining remote sensing and water balance approaches, Rechna Doab, Pakistan. Hydrogeology Journal 13, 653-664.

Arnold, J.G., R. Srinivasan, R.S. Muttiah, and J.R. Williams. 1998. Large-area hydrologic modeling and assessment: Part I. Model development. Journal of the American Water Resources Association 34, 73-89.

Arshad, M., N. Ahmed, and J.M. Cheema. 2008. Modeling approach for the assessment of recharge contribution to groundwater from surface irrigation conveyance system. Irrigation and Drainage Systems 22, 67-77.

Arshad, M., M.J.M. Cheema, and S. Ahmed. 2007. Determination of lithology and groundwater quality using electrical resistivity survey. International Journal of Agriculture and Biology 9, 143-146.

Arshad, M., M.R. Choudhry, and R.N. Ahmed. 2005. Groundwater recharge contribution from various components of irrigation water conveyance system of Rechna Doab of Punjab-Pakistan. Pakistan Journal of Water Resources 9, $17-24$.

Bastiaanssen, W.G.M., M.J.M. Cheema, W.W. Immerzeel, I. Miltenburg, and H. Pelgrum. 2012. The surface energy balance and actual evapotranspiration of the transboundary 
Indus Basin estimated from satellite measurements and the ETLook model. Water Resources Research 48, W11512.

Bastiaanssen, W.G.M., D.J. Molden, S. Thiruvengadachari, A.A.M.F.R. Smit, L. Mutuwatte, G. Jayasinghe. 1999. Remote sensing and hydrologic models for performance assessment in Sirsa irrigation circle, India. Research Report 27. International Water Management Institute, Colombo, Sri Lanka.

Beven, K. 2006. A manifesto for the equifinality thesis. Journal of Hydrology 320, 18-36.

Beven, K.J., and J. Freer. 2001. Equifinality, data assimilation, and uncertainty estimation in mechanistic modelling of complex environmental systems. Journal of Hydrology 249, $11-29$.

Cheema, M.J.M., and W.G.M. Bastiaanssen. 2010. Land use and land cover classification in the irrigated Indus Basin using growth phenology information from satellite data to support water management analysis. Agricultural Water Management 97, 1541-1552.

Cheema, M.J.M., and W.G.M. Bastiaanssen. 2012. Local calibration of remotely sensed rainfall from the TRMM satellite for different periods and spatial scales in the Indus Basin. International Journal of Remote Sensing 33, 2603-2627.

Droogers, P. 2006. Unpublished data on pedo-transfer functions. Wageningen, The Netherlands, Future Water.

FAO. 1995. FAO-UNESCO digital soil map of the world and derived soil properties. Paris: UNESCO.

Foster, S.S.D., and P.J. Chilton. 2003. Groundwater: The processes and global significance of aquifer degradation. Philosophical Transactions of the Royal Society of London. Series B: Biological Sciences 358, 1957-1972.

Githui, F., B. Selle, and T. Thayalakumaran. 2012. Recharge estimation using remotely sensed evapotranspiration in an irrigated catchment in southeast Australia. Hydrological Processes. 26, 1379-1389.

Habib, Z. 2004. Scope for reallocation of river waters for agriculture in the Indus Basin. PhD dissertation. ENGREF, Montpellier, France.

Harmel, R.D., R.J. Cooper, R.M. Slade, R.L. Haney, and J.G. Arnold. 2006. Cumulative uncertainty in measured streamflow and water quality data for small watersheds. Transactions of the ASABE 49, 689-701.

Healy, R., and P. Cook. 2002. Using groundwater levels to estimate recharge. Hydrogeology Journal 10, 91-109.

Hoffmann, L., A. El Idrissi, L. Pfister, B. Hingray, F. Guex, A. Musy, J. Humbert, G. Drogue, and T. Leviandier. 2004. Development of regionalized hydrological models in an area with short hydrological observation series. River Research and Applications 20, 243-254.

Huffman, G.J., R.F. Adler, D.T. Bolvin, G. Gu, E.J. Nelkin, K.P. Bowman, Y. Hong, E.F. Stocker, and D.B. Wolff. 2007. The TRMM multisatellite precipitation analysis (TMPA): quasiglobal, multiyear, combined-sensor precipitation estimates at fine scales. Journal of Hydrometeorology 8, 38-55.

Immerzeel, W.W., and P. Droogers. 2008. Calibration of a distributed hydrological model based on satellite evapotranspiration. Journal of Hydrology 349, 411-424.

Immerzeel, W.W., A. Gaur, and S.J. Zwart. 2008. Integrating remote sensing and a process-based hydrological model to evaluate water use and productivity in a south Indian catchment. Agricultural Water Management 95, 11-24.

IUCN. 2010. Beyond Indus Water Treaty: Ground Water and Environmental Management-Policy Issues and Options. Karachi, Pakistan, IUCN.

Jeevandas, A., R.P. Singh, and R. Kumar. 2008. Concerns of groundwater depletion and irrigation efficiency in Punjab agriculture: A micro-level study. Agricultural Economics Research Review 21, 191-199.

Kannan, N., J. Jeong, and R. Srinivasan. 2011. Hydrologic modeling of a canal irrigated agricultural watershed with irrigation best management practices: A case study. Journal of Hydrologic Engineering 16, 746-758.

Kreutzmann, H. 2011. Scarcity within opulence: Water management in the Karakoram Mountains revisited. Journal of Mountain Science 8, 525-534.

Kroes, J.G., P. Droogers, R. Kumar, W.W. Immerzeel, R.S. Khatri, A. Roelevink, H.W. ter Maat, D.S. Dabas. 2003. A regional approach to model water productivity. In Water Productivity of Irrigated Crops in Sirsa District, India. Integration of Remote Sensing, Crop and Soil Models and Geographical Information Systems, eds. J.C. Van Dam and R.S. Malik, 101-119. WATPRO Final Report.

Maupin, M.A. 1999. Methods to determine pumped irrigationwater withdrawals from the Snake River between upper Salmon Falls and Swan Falls dams, Idaho, using electrical power data,1990-95. U.S. Geological Survey Water-Resources Investigation Report 99-4175. Littleton, Colorado: USGS.

Monteith, J.L. 1965. Evaporation and environment. Symposia of the Society for Experimental Biology 19, 205-234.

Nash, J.E., and J.V. Sutcliffe. 1970. River flow forecasting through conceptual models part $1-\mathrm{A}$ discussion of principles. Journal of Hydrology 10, 282-290.

Neitsch, S.L., J.G. Arnold, J.R. Kiniry, and J.R. Williams. 2005. Soil and Water Assessment Tool-Theoretical documentation. Version 2005. Temple, Texas: Blackland Research \& Extension Center.

PARC. 1982. Consumptive use of water for crops in Pakistan. Final Technical Report, 20-30. Pakistan Agricultural Research Council, Islamabad, Pakistan.

Qureshi, A.S., T. Shah, and M. Akhtar. 2003. The groundwater economy of Pakistan. Working Paper 64. Lahore, Pakistan: International Water Management Institute.

Rodell, M., I. Velicogna, and J.S. Famiglietti. 2009. Satellitebased estimates of groundwater depletion in India. Nature 460, 999-1002.

Sarwar, A., and H. Eggers. 2006. Development of a conjunctive use model to evaluate alternative management options for surface and groundwater resources. Hydrogeology Journal 14, 1676-1687.

Scott, C.A., and T. Shah. 2004. Groundwater overdraft reduction through agricultural energy policy: Insights from India and Mexico. International Journal of Water Resources Development 20, 149-164.

Shah, T., J. Bruke, K. Vullholth, M. Angelica, E. Custodio, F. Daibes, J.D. Hoogesteger Van Dijk, M. Giordano, J. Girman, E. Kendy, J. Kijne, R. Llamas, M. Masiyandama, J. Margat, L. Marin, J. Peck, S. Rozelle, B. Sharma, L.F. Vincent, and J. Wang. 2007. Groundwater: A global assessment of scale and significance. In Water for Food: Water for Life. A Comprehensive Assessment of Water Management in Agriculture, ed. D. Molden, 395-423. London, UK, Colombo, Sri Lanka: IWMI, Earthscan.

Shah, T., D.J. Molden, R. Sakthivadivel, and D. Seckler. 2000. The Global Groundwater Situation: Overview of Opportunities and Challenges. Colombo, Sri Lanka: International Water Management Institute.

Shankar, P.S.V., H. Kulkarni, and S. Krishnan. 2011. India's groundwater challenge and the way forward. Economic and Political Weekly XLVI, 37-45.

Siebert, S., J. Burke, J.M. Faures, K. Frenken, J. Hoogeveen, P. Doll, and F.T. Portmann. 2010. Groundwater use for irrigation-A global inventory. Hydrology and Earth System Sciences 14, 1863-1880.

Sivapalan, M., K. Takeuchi, S.W. Franks, V.K. Gupta, H. Karambiri, V. Lakshmi, X. Liang, J.J. McDonnell, E.M. Mendiondo, P.E. O'Connell, T. Oki, J.W. Pomeroy, D. Schertzer, S. Uhlenbrook, and E. Zehe. 2003. IAHS Decade on Predictions in Ungauged Basins (PUB), 2003-2012: Shaping an exciting future for the hydrological sciences. Hydrological Sciences Journal 48, 857-880. 
Srinivasan, R., T.S. Ramanarayanan, J.G. Arnold, and S.T. Bednarz. 1998. Large area hydrologic modeling and assessment: Part II. Model application. Journal of the American Water Resources Association 34, 91-101.

Srinivasan, R., X. Zhang, and J. Arnold. 2010. SWAT ungauged: hydrological budget and crop yield predictions in the Upper Mississippi River Basin. Transactions of the ASABE 53, $1533-1546$.
Thornton, P.E., S.W. Running, and M.A. White. 1997. Generating surfaces of daily meteorological variables over large regions of complex terrain. Journal of Hydrology 190, 214-251.

Zhang, X., R. Srinivasan, and M.V. Liew. 2008. Multi-site calibration of the SWAT model for hydrologic modeling. Transactions of the ASABE 51, 2039-2049.

\section{NGWA Conference on Hydrology and Water Scarcity in the Rio Grande Basin (\#5034) February 25-26, 2014 • Albuquerque, New Mexico}

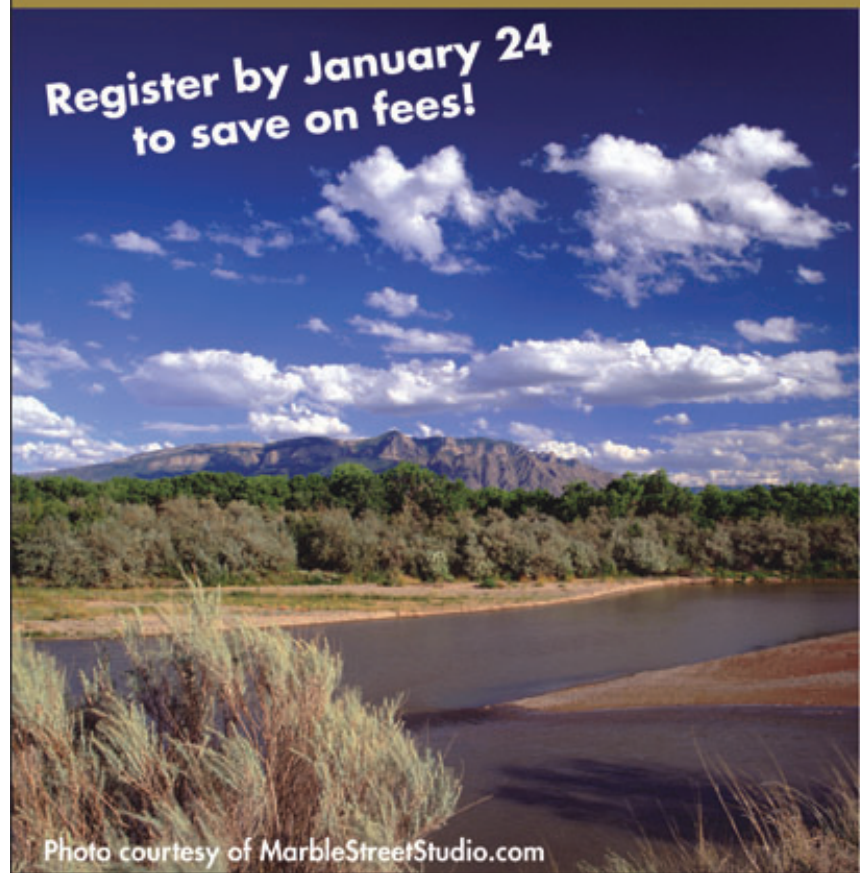

Join fellow groundwater professionals to discuss what is known about the quantity, quality, and interconnections of the groundwater and surface water resources in the Rio Grande Basin, which encompasses the states of Colorado, New Mexico, and Texas, plus part of Mexico. Record low flows and storage in reservoirs highlight groundwater in this region as both a hedge against drought and an important resource to manage effectively. Topics to be explored include:

- Water supply/shortage

- Water quality

- Legal frameworks.

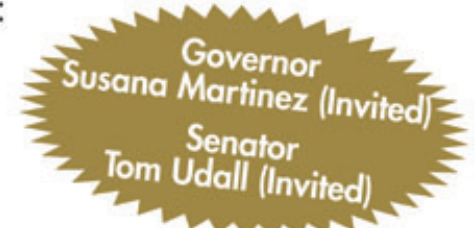
Don't delay - save by registering today! $800551.7379 \cdot 614898.7791$ 